\title{
KETAMINE-XYLAZINE ANESTHESIA IN RED-TAILED HAWKS WITH ANTAGONISM BY YOHIMBINE
}

\author{
Laurel A. Degernes,' Terry J. Kreeger, ${ }^{2}$ Ronald Mandsager, ${ }^{3}$ and Patrick T. Redig' \\ ' Raptor Research and Rehabilitation Program, University of Minnesota, St. Paul, Minnesota 55108, USA \\ 'Department of Fisheries and Wildlife, University of Minnesota, St. Paul, Minnesota 55108, USA \\ ${ }^{3}$ Department of Small Animal Clinical Sciences, College of Veterinary Medicine, University of Minnesota, \\ St. Paul, Minnesota 55108, USA
}

ABSTRAC:T: Five red-tailed hawks (Buteo jamaicensis) were anesthetized at weekly intervals with intravenous ketamine hydrochloride (KET, $4.4 \mathrm{mg} / \mathrm{kg}$ ) and xylazine hydrochloride (XYL, $2.2 \mathrm{mg}$ / $\mathrm{kg}$ ). Twenty min after anesthesia, yohimbine hydrochloride ( $\mathrm{YOH}, 0.05,0.10,0.20$ and $0.40 \mathrm{mg} /$ $\mathrm{kg})$ or a control was administered. All doses of $\mathrm{YOH}$ significantly reduced the head-up times $(\mathrm{F}=$ $20.84, \mathrm{df}=1,24, P<0.0001)$ and the standing times $(\mathrm{F}=12.30, \mathrm{df}=1,24, P<0.0001)$, compared to the control group. The heart and respiratory rates following YOH (all doses) were significantly greater $(P<0.01)$ than the anesthetized rates, but were comparable to the rates observed in restrained, unanesthetized hawks. Yohimbine did not appear to have any significant effect on body temperature. Based upon administration of $4.4 \mathrm{mg} / \mathrm{kg} \mathrm{KET}$ and $2.2 \mathrm{mg} / \mathrm{kg} \mathrm{XYL}$, a dose of 0.10 $\mathrm{mg} / \mathrm{kg} \mathrm{YOH}$ was recommended to achieve antagonism without causing profound cardiovascular or respiratory changes.

Key words: Red-tailed hawk, Buteo jamaicensis, ketamine hydrochloride, xylazine hydrochloride, yohimbine hydrochloride, heart rate, respiratory rate, anesthesia, antagonism, experimental study.

\section{INTRODUCTION}

The combination of the alpha-2 adrenergic agonist xylazine hydrochloride (XYL) and the cyclohexane, ketamine hydrochloride (KET) has been an effective anesthetic agent in many mammalian (Jessup et al., 1983; Hsu and Lu, 1984; Kreeger et al., 1987) and avian species (Amand, 1980; Haigh, 1981; Samour et al., 1984; Harrison et al., 1985). The synergistic action of XYL with KET results in smooth induction and recovery, improved muscle relaxation, enhanced analgesia, and a decreased total dose of either drug compared to their use alone (Amend, 1972). Typically, the recovery period from this drug combination may be prolonged, but the alpha-2 adrenergic antagonist, yohimbine hydrochloride $(\mathrm{YOH})$ has been shown to effectively reduce the recovery times in many wild and domestic mammalian species (Jessup et al., 1983; Hsu and Lu, 1984; Mech et al., 1985; Kreeger and Seal, 1986b; Kreeger et al., 1987). The use of $\mathrm{YOH}$ as a XYL or $\mathrm{KET} / \mathrm{XYL}$, antagonist in avian species has been demonstrated in 1-3-day-old Leghorn chicks and adult Guineafowl
(Numida meleagris) (Hsu, 1981; Teare, 1987).

In certain field and clinical studies requiring short-term anesthesia, it would be desirable to antagonize KET/XYL anesthesia. The purpose of this study was to determine the efficacy of $\mathrm{YOH}$ antagonism of KET/XYL anesthesia in red-tailed hawks (Buteo jamaicensis) and the effects upon their cardiovascular and respiratory parameters.

\section{MATERIALS AND METHODS}

Five permanently crippled red-tailed hawks obtained from the Raptor Research and Rehabilitation Program (RRRP; University of Minnesota, St. Paul, Minnesota 55108, USA) were used in the study. There were three males and two females, as determined by endoscopy (weight range 990-1450 g). All birds were twowinged and remained healthy during the study, as determined by physical examinations and hematological parameters. These birds were housed in a large indoor flight room where lighting and temperature were artificially controlled. They were fed killed laboratory rodents or poultry every other day and provided water ad libitum.

The birds were anesthetized at weekly intervals in a crossover design using $4.4 \mathrm{mg} / \mathrm{kg} \mathrm{ke}$ tamine (Ketaset, Bristol Laboratories, Syracuse, New York 13201, USA) and $2.2 \mathrm{mg} / \mathrm{kg}$ xylazine 
(Rompun, Haver-Lockhart Laboratories, Shawnee, Kansas 66201, USA). These drugs were combined and administered intravenously (i.v.) in the basilic vein. Since induction generally occurred in $<10 \mathrm{sec}$, the time of injection was considered the start of the $20 \mathrm{~min}$ anesthesia period. The feet were taped for operator safety and the birds were placed in dorsal recumbancy on a padded table.

Yohimbine hydrochloride (Sigma Chemical Company, St. Louis, Missouri 63178, USA) was dissolved in sterile saline to yield a solution containing $0.5 \mathrm{mg} / \mathrm{ml} \mathrm{YOH}$. At $20 \mathrm{~min}$ postinduction, the hawks were given one of four doses of YOH $(0.05,0.10,0.20$ and $0.40 \mathrm{mg} / \mathrm{kg}) \mathrm{i} . \mathrm{v}$. , or an equivalent volume of sterile $0.9 \%$ saline.

Heart rates (HR) and respiratory rates (RR) were monitored during the preanesthesia period, the 20 - $\mathrm{min}$ anesthesia period $(5-\mathrm{min}$ intervals) and the 10-min recovery period (1-min intervals following $\mathrm{YOH}$ ). The RR were counted by visual inspection and HR were measured using an electrocardiograph (Datascope 871 Monitor, Datascope Corp., Paramus, New Jersey 07652 , USA). Body temperatures were monitored during the anesthesia and recovery periods using a cloacal probe (Monitemp Digital Temperature Recorder, American Hospital Supply, Minneapolis, Minnesota 55402, USA). The temperature probes were usually expelled from the cloaca within 5 min following $\mathrm{YOH}$ due to increased muscle tone and activity.

Head-up times (HUT) and standing times (ST) were recorded following YOH. The HUT was the time at which the hawk opened its eyes and raised its head. The $\mathrm{ST}$ was the time required for the bird to stand unassisted by wing or tail support without ataxia.

Statistical analysis were by two-way analysis of variance and Tukey's Pairwise Comparisons. A $P$-value of $\leq 0.05$ was considered significant (Snedecor and Cochran, 1980).

\section{RESULTS}

The HUT and ST after YOH administration were significantly shorter $(P<$ $0.0001)$ than those of the control group (Table 1). These effects were observed at the lowest doses of YOH and no significant improvements were gained using the higher YOH doses. Statistically, there were no differences between the four $\mathrm{YOH}$ groups for these parameters.

During anesthesia, the HR were significantly lower $(P<0.0001)$ than prior to anesthesia (Fig. 1). Administration of the control solution did not alter the HR in the
TABLE 1. Head-up (HUT) and standing times (ST) for red-tailed hawks anesthetized with $4.4 \mathrm{mg} / \mathrm{kg}$ ketamine and $2.2 \mathrm{mg} / \mathrm{kg}$ xylazine, followed by yohimbine (YOH) administration.

\begin{tabular}{|c|c|c|c|}
\hline $\begin{array}{l}\text { Dose of } \\
\text { YOH } \\
\text { (mg } \mathrm{kg})\end{array}$ & $n$ & $\begin{array}{c}\text { HLT (min) } \\
\text { Mean } \pm \mathrm{SE} \\
\text { Range }\end{array}$ & $\begin{array}{l}\mathrm{ST}(\min ) \\
\text { Mean } \pm \mathrm{SE} \\
\text { Range }\end{array}$ \\
\hline Control & 5 & $\begin{array}{c}14.6 \pm 2.6 \\
10-24\end{array}$ & $\begin{array}{c}86.4 \pm 16.0 \\
47-124\end{array}$ \\
\hline 0.05 & 5 & $\begin{array}{c}4.2 \pm 1.5^{+1} \\
1-9\end{array}$ & $\begin{array}{c}31.6 \pm 9.2 \\
9-63\end{array}$ \\
\hline 0.10 & 5 & $\begin{array}{l}1.2 \pm 0.2+1 \\
1-2\end{array}$ & $\begin{array}{c}12.8 \pm 4.4 \\
5-30\end{array}$ \\
\hline 0.20 & 5 & $\begin{array}{c}1.2 \pm 0.2 \cdot 1 \\
1-2\end{array}$ & $\begin{array}{c}15.6 \pm 2.4^{41} \\
9-24\end{array}$ \\
\hline 0.40 & 5 & $\begin{array}{l}1.0^{n} \\
1\end{array}$ & $\begin{array}{c}14.4 \pm 2.8 \cdot 1 \\
7-22\end{array}$ \\
\hline
\end{tabular}

- Significantly different from control value at $P<0.0 .5$.

1. No significant difference between YOH doses at $P>0.0 .5$.

anesthetized birds ( $P>0.05$; Fig. 2). Following YOH administration (all doses), the HR were higher $(P<0.01)$ than those recorded during the anesthesia period. During the first $3 \mathrm{~min}$ following $\mathrm{YOH}$, there was a steep linear increase in $\mathrm{HR}$ for the three higher doses $(r=0.8211, P<$ $0.0001, n=45$ ), after which the rates tended to stabilize. The time interval between 2 and $5 \mathrm{~min}$ post $\mathrm{YOH}$ was used to compare the effects of different doses on HR and RR (Table 2). This interval represents the maximal response to $\mathrm{YOH}$. Because of the birds arousal following $\mathrm{YOH}$, observations beyond $5 \mathrm{~min}$ had enough missing data points to prevent precise statistical analysis. The HR following 0.10 and $0.20 \mathrm{mg} /$ $\mathrm{kg} \mathrm{YOH}$ were not significantly different from each other during this interval, but were higher than the control and $0.05 \mathrm{mg} /$ $\mathrm{kg}$ groups and lower than the $0.40 \mathrm{mg} / \mathrm{kg}$ group $(P<0.05 ;$ Table 2$)$.

The RR were lower during anesthesia $(P<0.01)$ than prior to anesthesia (Fig. 1). Administration of the control (saline) did not alter the RR in the anesthetized hawks $(P>0.05)$. Following YOH administration, there was a significant increase $(P<0.05)$ in RR compared to those observed during anesthesia (all doses). The mean RR observed during the interval from 


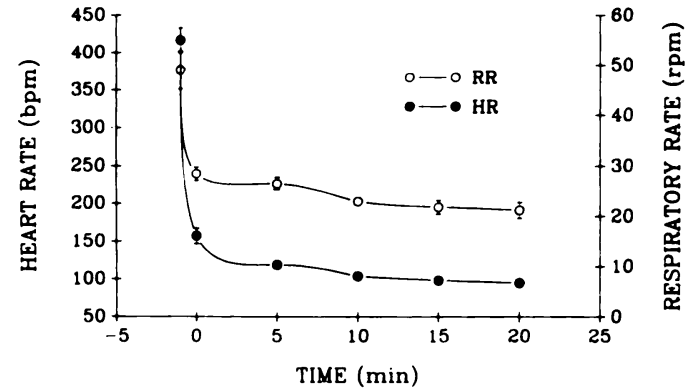

FIC: RE 1. Heart rates (beats per min; bpm) and respiratory rates (respirations per $\mathrm{min}$; $\mathrm{rpm}$ ) in redtailed hawks immediately prior to anesthesia (restrained), and for $20 \mathrm{~min}$ following i.v. administration of $4.4 \mathrm{mg} / \mathrm{kg}$ ketamine and $2.2 \mathrm{mg} / \mathrm{kg}$ xylazine. Symbols without error bars had very small standard errors.

2 to $5 \mathrm{~min}$ were not statistically different from each other following 0.05 and 0.10 $\mathrm{mg} / \mathrm{kg} \mathrm{YOH}(P>0.05)$, but were higher than the control group and lower than the 0.20 and $0.40 \mathrm{mg} / \mathrm{kg}$ YOH groups $(P<$ 0.05; Table 2).

The HR and RR following all doses of YOH were not as high as those observed in restrained hawks prior to anesthesia ( $\mathrm{Ta}$ ble 2).

Body temperatures decreased from 40.5 $\pm 0.2 \mathrm{C}$ to $40.0 \pm 0.2 \mathrm{C}$ during anesthesia (20 min). No significant changes in body temperature were noted following $\mathrm{YOH}$ administration $(P>0.05)$.

TABLE: 2. Heart (HR) and respiratory (RR) for redtailed hawks anesthetized with $4.4 \mathrm{mg} / \mathrm{kg}$ ketamine and $2.2 \mathrm{mg} / \mathrm{kg}$ xylozine, followed by yohimbine (YOH) administration (mean $\pm \mathrm{SE}$ for data collected between 2 and $5 \mathrm{~min}$ ). Preanesthesia (restrained) HR and $\mathrm{RR}$ are included for comparison.

\begin{tabular}{|c|c|c|}
\hline $\begin{array}{l}\text { YOH dose } \\
\text { (mg kg) }\end{array}$ & HR (bpm) & $\mathrm{RK}(\mathrm{rpm}) \cdot$ \\
\hline Control & $88.2 \pm 3.1$ & $20.5 \pm 1.5$ \\
\hline 0.05 & $167.8 \pm 16.5$ & $30.2 \pm 1.7$ \\
\hline 0.10 & $315.1 \pm 23.3$ & $35.7 \pm 2.0$ \\
\hline 0.20 & $333.4 \pm 24.6$ & $42.7 \pm 2.7$ \\
\hline 0.40 & $408.6 \pm 11.3$ & $40.4 \pm 1.1$ \\
\hline Preanesthesiat & $416.5 \pm 16.7$ & $49.1 \pm 3.8$ \\
\hline
\end{tabular}

- Bpm. beats per min: rpm, respirations per min

1. Preanesthesia data represent an average of $1 \mathrm{~min}$ prior to induction.

Significantly different from control value at $P<0.05$

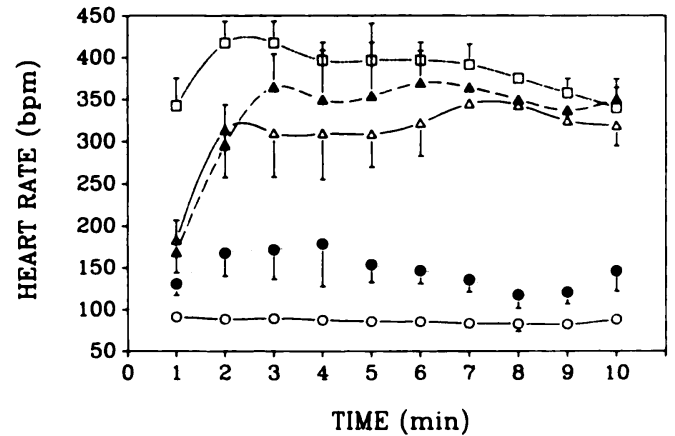

Figure 2. Heart rates (beats per min; bpm) following i.v. administration of a control (O); $0.05 \mathrm{mg} /$ $\mathrm{kg}$ yohimbine $(\mathrm{YOH})(\triangle) ; 0.10 \mathrm{mg} / \mathrm{kg} \mathrm{YOH}(\triangle) ; 0.20$ $\mathrm{mg} / \mathrm{kg}$ YOH $(\triangle) ; 0.40 \mathrm{mg} / \mathrm{kg}$ YOH ( $\square)$. Symbols without error bars had very small standard errors.

\section{DISCUSSION}

Xylazine is an alpha-2 adrenergic agonist that stimulates central presynaptic adrenoceptors, preventing norepinephrine release at the nerve terminal to produce sedation and analgesia (Starke, 1977; Doxey and Roach, 1980). In many avian species, XYL does not produce immobilization adequate for most surgical procedures. Other problems include respiratory depression, hypotension, bradycardia, excitement and convulsions in both mammals and birds, and prolonged recovery times of up to $12 \mathrm{hr}$ (Amand, 1980; Hatch et al., 1982; Samour et al., 1984).

The site of action of ketamine has yet to be defined, but may include cholinergic, serotonergic, dopaminergic, or opioid receptors (Finck and Ngai, 1982; White et al., 1982; Leeuwin et al., 1984). Ketamine has limited use as an avian anesthetic agent when used alone because of inadequate analgesia and muscle relaxation during surgery and sometimes violent recoveries (Boever and Wright, 1975; Altman, 1980; Redig et al., 1984; Samour et al., 1984). Variability to response by different avian species has been reported (Redig and Duke, 1976).

Yohimbine is an alpha-2 adrenergic antagonist (Goldberg and Robertson, 1983) that has been used extensively to reverse 
XYL or KET/XYL anesthesia in many domestic (Hsu, 1983; Hsu and Lu, 1984) and wild mammals (Jessup et al., 1983; Mech et al., 1985; Ramsey et al., 1985; Kreeger and Seal, 1986b; Kreeger et al., 1987), and in two avian species (Hsu, 1981; Teare, 1987).

The effect of YOH reversal of KET anesthesia is more controversial. It has been suggested that $\mathrm{YOH}$ acts as a central stimulant to override some of the effects of KET (Hsu and Lu, 1984). However, in certain mammals anesthetized with KET followed by $\mathrm{YOH}$ antagonism, there was no reduction in walk time (Hatch et al., 1982; Kreeger and Seal, 1986a). Red-tailed hawks anesthetized with $30 \mathrm{mg} / \mathrm{kg}$ i.v. $\mathrm{KET}$, followed by $0.10 \mathrm{mg} / \mathrm{kg} \mathrm{YOH}$ did not have shorter recovery times when compared to controls (Degernes, unpubl. data).

The KET/XYL anesthetic dose routinely used in red-tailed hawks at the Raptor Research and Rehabilitation Program is $10.0 \mathrm{mg} / \mathrm{kg} \mathrm{KET}$ and $2.0 \mathrm{mg} / \mathrm{kg} \mathrm{XYL}$, combined and administered i.v. (Redig, unpubl. data). In pilot studies, we found that hawks anesthetized with this 5:1 KET/ $\mathrm{XYL}$ ratio exhibited difficult recoveries following YOH antagonism, presumably due to the cataleptic effects of residual KET after XYI, had been antagonized. After experimentation, we determined that 2:1 KET/XYL (4.4 mg/ $\mathrm{kg} \mathrm{KET}$ and 2.2 $\mathrm{mg} / \mathrm{kg} \mathrm{XYL)} \mathrm{provided} \mathrm{the} \mathrm{lowest} \mathrm{possible}$ dose of KET to achieve an adequate level of anesthesia for short-term diagnostic or surgical procedures (under $15 \mathrm{~min}$ ). By using the reduced dose of KET, YOH antagonism of XYL, resulted in smoother recoveries for the hawks. Other researchers have found this $2: 1 \mathrm{ratio}(4.0 \mathrm{mg} / \mathrm{kg} \mathrm{KET}$ and $2.0 \mathrm{mg} / \mathrm{kg}$ XYL) to be effectively antagonized by $\mathrm{YOH}$ in coyotes (Kreeger and Seal, 1986b).

The four YOH doses were selected to determine the optimum reversal dose with the fewest side effects. The rise in $\mathrm{HR}$ and RR following all doses of $\mathrm{YOH}$ were not as high as those observed in restrained, pre- anesthetized birds, and therefore are probably not pharmacologically induced. Yohimbine has been shown to cause minimal effect on HR as a result of direct cardiac action (Gomes et al., 1980). At no time were any ECG abnormalities recorded for any of these hawks.

\section{CONCLUSIONS}

A dose of $4.4 \mathrm{mg} / \mathrm{kg} \mathrm{KET}$ and $2.2 \mathrm{mg} /$ $\mathrm{kg}$ XYL provided adequate short-term anesthesia for red-tailed hawks. A dose of $0.10 \mathrm{mg} / \mathrm{kg} \mathrm{YOH}$ was the lowest dose required to significantly reduce HUT and ST and did not result in profound cardiovascular or respiratory responses.

\section{ACKNOWLEDGMENTS}

We would like to thank Susan B. Chaplin for her editorial assistance. The monitoring equipment was provided by the Department of Small Animal Clinical Sciences, College of Veterinary Medicine, University of Minnesota. This work was supported by the University of Minnesota Raptor Research and Rehabilitation Program.

\section{LITERATURE CITED}

AlTMAl, R. B. 1980. Avian anesthesia. The compendium on continuing education for the practicing veterinarian, Vol. 2, American Veterinary Medical Association, Schaumburg, Illinois, pp. $38-42$.

AMANI, W. B. 1980. Avian anesthetic agents and techniques-A review. In American Association of Zoo Veterinarians, Annual Proceedings. American Association of Zoo Veterinarians, Washington, D.C., pp. 68-72.

A(t: I), J. F. 1972. Premedication with xylazine to eliminate muscular hypertonicity in cats during ketamine anesthesia. Veterinary Medicine and Small Animal Clinician 67: 1305-1307.

Borirk, W. J., ANI) W. Whicirt. 1975. L'se of ketamine for restraint and anesthesia of birds. Veterinary Medicine and Small Animal Clinician 70: 86-88.

Doxk, J. C., ANI) A. G. Ro.I(H. 1980. Presynaptic alpha-adrenoceptors, in vitro methods and preparations utilized in the evaluation of agonists and antagonists. Journal of Autonomic Pharmacology 1: 73-99.

FINc:k, A. D., INI) S. H. Ni:II. 1982. Opiate receptor mediation of ketamine analgesia. Anesthesiology 56: 291-297.

Goldmik(; M. R., NNI) D. Robritson. 1983. Yo- 
himbine: A pharmacological probe for study of the alpha- 2 adrenoreceptor. Pharmacology Review 35 : $143-180$.

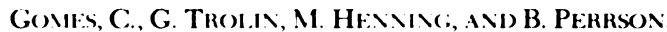
1980. Pre- and post-synaptic alpha-adrenoceptor antagonists: Differentiated cardiovascular effects in the rat. Clinical Experimental Hypertension 2: 273-296.

HAIC:H, J. C. 1981. Anesthesia of raptorial birds. In Recent advances in the study of raptor diseases, J. E. Cooper and A. Greenwood (ed.). Chiron Publications, Keighley, England, pp. 61-66.

Harrison, G. J., K. A. Christrisisen, J. F. CrawF(OHI), M. S. Millik, AND H. L. Sulvaphasad. 1985. A clinical comparison of anesthetics in domestic pigeons and cockatiels. In Proceedings of the Annual Meeting of the Association of Avian Veterinarians. Association of Avian Veterinarians, Lake Worth, Florida, pp. 7-22.

Hatch, R. C., N. H. Booth, J. D. Clakk, L. M. CRAWfORD, J. V. KITZMAI, AND B. Wallnek. 1982. Antagonism of xylazine sedation in dogs by 4-aminopyridine and yohimbine. American Journal of Veterinary Research 43: 1009-1014.

Hst , W. H. 1981. Xylazine-induced depression and its antagonism by alpha-adrenergic blocking agents. The Journal of Pharmacology and Experimental Therapeutics 218: 188-192.

. 1983. Effect of yohimbine on xylazine-induced central nervous system depression in dogs. Journal of the American Veterinary Medical Association 182: 698-699.

- AND Z. X. L(. 1984. Effect of yohimbine on xylazine-ketamine anesthesia in cats. Journal of the American Veterinary Medical Association 185: 886-888.

Jesst P, D. A., W. E. Ciakk, P. A. Gullett, AND K. R. JoNFs. 1983. Immobilization of mule deer with ketamine and xylazine and reversal of immobilization with yohimbine. Journal of the American Veterinary Medical Association 183: 1339-1340.

Krhegik, T. J., A. M. Fici(illa, U. S. Stal, L. D. Mech, M. CallahaN, AND B. Hal.L. 1987. Cardiovascular and behavioral responses of gray wolves to ketamine hydrochloride-xylazine hydrochloride immobilization and antagonism by yohimbine hydrochloride. Journal of Wildlife Diseases 23: 463-470.

-, ANI) U. S. SFAl. 1986a. Failure of yohimbine hydrochloride to antagonize ketamine hydrochloride immobilization of gray wolves. Journal of Wildlife Diseases 22: 600-603.
, ANI - 1986b. Immobilization of coyotes with xylazine hydrochloride-ketamine hydrochloride and antagonism by yohimbine hydrochloride. Journal of Wildlife Diseases 22: 604606.

Leeuwin, R. S., J. K. van der Wal, and W. Spanjer. 1984. Interaction of cholinesterase inhibitors and glucocorticoids with ketamine and pentobarbitone-induced general anesthesia in the rat: Possible effects of central cholinergic activity. British Journal of Pharmacology 82: 339-347.

Mecil, L. D., G. D. DelGiudice, P. D. KaRNS, AND U. S. SEAL. 1985. Yohimbine hydrochloride as an antagonist to xylazine hydrochloride immobilization of white-tailed deer. Journal of Wildlife Diseases 21: 405-410.

Ranisey, M. A., I. Stirling, L. D. Knt tsei, and E. Brocguton. 1985. Use of yohimbine hydrochloride to reverse immobilization of polar bears by ketamine hydrochloride and xylazine hydrochloride. Journal of Wildlife Diseases 21: 396400.

REDIG, P. T., AND G. E. DikE. 1976. Intravenously administered ketamine $\mathrm{HCl}$ and diazepam for anesthesia of raptors. Journal of the American Veterinary Medical Association 169: 886-888.

, A. A. Larson, G. E. Dike. 1984. Response of Great-horned owls given optical isomers of ketamine. American Journal of Veterinary Research 45: 125-127.

Samotr, J. H., D. M. Jones, J. A. KNigit, ANI) J. C. HowleTt. 1984. Comparative studies of the use of some injectable anesthetic agents in birds. Veterinary Record 115: 6-11.

SNedecor, G. W., AND W. G. Cochran. 1980. Statistical methods, 7th ed. Iowa State University Press, Ames, lowa, 507 pp.

STARKE, K. 1977. Regulation of noradrenaline release by presynaptic receptor systems. Reviews of Physiology, Biochemistry, and Pharmacology 77: $1-124$.

Teare, J. A. 1987. Antagonism of xylazine hydrochloride-ketamine hydrochloride immobilization in Guineafowl (Numida meleagris) by yohimbine hydrochloride. Journal of Wildlife Diseases 23: 301-305.

White, P. F., W. L. WAY, AND A. J. TrFior. 1982. Ketamine-Its pharmacology and therapeutic uses. Anesthesiology 56: 119-136.

Received for publication 26 June 1987. 